\title{
Determinants of Business Survivability: Literature Review
}

\author{
Michał Kozak \\ Faculty of Economics \\ Maria Curie-Sktodowska University in Lublin, Poland \\ info@michalkozak.eu
}

\begin{abstract}
Purpose - The goal of this article was to define the concept of business survivability on the basis of a review of subject literature, as well as to identify the main determinants influencing the survivability of micro and small businesses based on an analysis of empirical studies that most often included a five-year observation of an enterprise - from the moment of its establishment, until it was deregistered, or the observation period was over.

Design/Methodology/Approach - The author utilises a review of Polish and foreign subject literature, as well as secondary research regarding the survivability of micro and small businesses in the $20^{\text {th }}$ and $21^{\text {st }}$ centuries.

Findings - The results suggest significant differences in business survivability depending on the country of origin of a given enterprise. The factors determining business survivability were divided into micro and macroeconomic, and their presence is vital for the company to persevere in turbulent market conditions.

Originality/Value - This article is a compilation of definitions of business survivability across foreign and Polish studies of micro and small businesses after 2000. The paper compares the results of business survivability in Poland and western countries.
\end{abstract}

Keywords - business survival, critical success factors, collapse of enterprises, micro business, small business

\section{Introduction}

It is a fact that micro, small, and medium enterprises are the driving force in economic development, and their survivability directly influences the condition of economy. They take part in generating approximately 50\% GDP in Poland, and provide work for $69 \%$ of people employed in companies (PARP, 2017).

To date, studies suggest that business survivability in Poland during the first years after registering the enterprise is significantly lower than business survivability in the countries of Western Europe, despite the fact that in western countries the market is more saturated, individual sectors have more competing entities, and the entry barriers are higher.

Business survivability is defined, according to literature regarding business demography, as the moment of birth, i.e. entering the Register of Entrepreneurs (CEIDG - Central Registration and Information on Economic Activity, KRS - National Court Register), and the moment of death of an enterprise, i.e. deregistering from

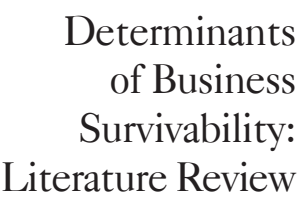


IJSR

6 an entrepreneurs database, which can be defined more broadly not only as closing or suspending its activity, but also as insolvency or bankruptcy.

The field of research and observation regarding business survivability in Poland is relatively young, since studies were carried out only after 2000 , and the study group consisted of micro and small enterprises where internal factors influencing the company's ability to stay on the market were investigated. In the literature from Western Europe, first studies began appearing 40 years ago, discussing micro, small, and big enterprises. In the case of bigger companies, literature predominantly pertains to descriptions of industrial theories, competition theories, and market behaviours, which does not holistically portray the relations in terms of factors of business survivability due to a limited amount of analytical material, which is a consequence of unwillingness of companies to share this type of information. The data was taken mainly from the surveys by Polish Central Statistical Office and Eurostat and provides limited opportunities of investigating all business survivability factors that should be divided into micro- and macroeconomic.

An important issue for studying survivability is the level of Critical Success Factors, i.e. a set of factors that allow an enterprise to obtain a competitive advantage. According to Grunert and Ellegaard (1992), critical success factors include "resources and abilities, that the company invests in its respective market, that explain the majority of differences in obtained value, and in costs borne". What is more, they determine development and growth, as well as slowdown and collapse. They also provide information as to in which sectors of the enterprise one should focus strategic decisions, thus, ensuring future success of the company.

The goal of this article was to revise Polish and foreign subject literature in order to compare the definitions of business survivability, as well as to highlight pivotal factors that influence the success of an enterprise. Chapter 2 of this paper presents the definitions of survivability, classification of symptoms of collapse and bankruptcy. Chapter 3 discusses the issue of key success factors that can directly protect a company from bankruptcy, given that they are implemented in time. Chapter 4 consists of a revision of empirical studies from all over the world, complete with a comparison of their results. The article ends with Chapter 5, which lists elements especially worth of attention, since they influence the condition of the company, including collapse or market success. Thus far, the majority of studies found in literature referred to factors available to the company at the beginning of its existence, or pertaining to its characteristics. There were no attempts to study a company throughout a longer period of time, after implementing an element aimed at increasing its effectiveness. In future studies it is important to investigate the condition of a company before and after implementing an improvement, as well as measure the effects of such an action.

\section{Definition of survivability}

Establishing new companies and the constant presence of already existing companies on the market are symptoms of economic liveliness. Starting a company is a process involving human and financial capitals of the entrepreneur. A collapse of enterprises affects the subjects engaged in its functioning, as well as their communities. While attempting to define business survivability one can encounter numerous references to 
surviving on the market as the main goal of an enterprise, next to generating profit. Recognising the factors that shape the establishment and survival of companies increases the probability of success of these companies, as well as of the entire economy. In literature, survival of a company is understood as the ability of an entity to remain on the market, that still exists during observation, which is equivalent to the lack of its liquidation and unhindered activity on the market. European Union regulation defines survivability as an enterprise that was established in the year ( $\mathrm{t}-1)$ that has survived in the year $(\mathrm{t})$ if it was active in every point of time in the given year $(\mathrm{t})$, and employs at least one person (survival without changes). There is another term - survival by takeover - that is, a take-over by another company, that employs at least one person, and was established in order to take over the means of production of that enterprise in the year (t). Factors related to establishment and collapse of existing enterprises vary across countries and individual regions of a given country. They differ in individual years, due to the fact that the process of establishing and liquidating a company is influenced by internal and external factors.

Survivability analysis can be carried out using demographic methods relating, in their primary design, to human population demography, however, due to its universal character, can be used to study business enterprises. The subject of such studies is the process of births and deaths of companies. This allows to create a coefficient for the dynamics of establishing companies, as well as for their market exits. The birth of an enterprise can be defined as the moment of its entry into the market, which is equivalent to making an entry into the National Court Register or Register of Entrepreneurs, however, this can be a result of creating an entirely new business, taking over an existing one, changing its ownership or legal form. The definition of an enterprise established in the year (t-1) (Real birth), according to European Union Regulation No 2700/98, or of one that has "survived from the previous year to (t-1) - is a company that survived in the year $(\mathrm{t})$, if it is active in terms of presence of turnover or employment in any given moment of the year $(\mathrm{t})$ (= survival without changes)". In more objective analyses, research encompasses only the companies that emerged on the market for the first time. The death of an enterprise, i.e. exiting the market, is equal to terminating ongoing activity, deregistering from National Court Register or Central Registration and Information on Economic Activity. It can mean the end of business activity, or its temporary suspension. Causes of such deaths usually involve loss of financial liquidity, and lack of ability to perform timely settlement of liabilities, i.e. insolvency and bankruptcy. It is also possible for the death of a company to take on a less negative form, as in the case of selling a functioning company, or merging with another company, both of which aim to generate profit. From the point of view of a company, termination of activity is a negative experience. According to the theory of economics, the mechanism of a selfregulating market is a desired phenomenon, since it is a precondition for proper market development, however, it is inseparable from collapsing and leaving the market in the case of most poorly adapted enterprises.

Due to the complex structure of business survivability determinants, while reviewing subject literature one should focus on the classification of symptoms indicating any danger to future functioning of the company. One such approach is classification according to accountancy, which is a source of information and data regarding the financial situation of
Determinants of Business Survivability: Literature Review 


\section{IJSR}

6

Table 1.

Selected development factors for small and medium enterprises companies. It divides the symptoms into financial and non-financial ones. The first group includes: permanent drop in income from sales, net loss, or decrease in net profit visible in profit and loss statement, difficulty in collecting receivables from debtors, increase in liabilities, as well as increasing numer of debtors, increased need for credit line especially for financing ongoing operations, timeliness of payments, increase in work in progress, increase in expired stock, sudden sales of assets below market prices, negative cashflow. The second group relates to symptoms non-financial in character: loss of strategic outlets, decrease in number of clients, issues with suppliers, difficulties in human resources management, lack of adaptation to technological changes, turbulent changes in legislation.

The causes of collapse of enterprises that are economical in character are divided in literature into microeconomic and macroeconomic. The first group relates to the inside of the company, and includes such elements as: organisational structure, management system, and economic information. The management can regulate all elements and influences their functioning. The second group - macroeconomic causes - does not depend on the enterprise and relates to its environment. The direct environment includes the situation in the industry and competitive position in the sector, while the indirect environment means the situation in the country and its economic fluctuations, such as interest rates, unemployment, average income in the comunity. It is also important to consider the world/global perspective of macroeconomic causes, including: international changes in economy and politics, prices of energy, international conflicts (Table 1). According to Mączyńska (2009), it can be concluded that due to the crisis it was discovered that companies are unprepared for future challenges, as well as how weak they are in early threat identification.

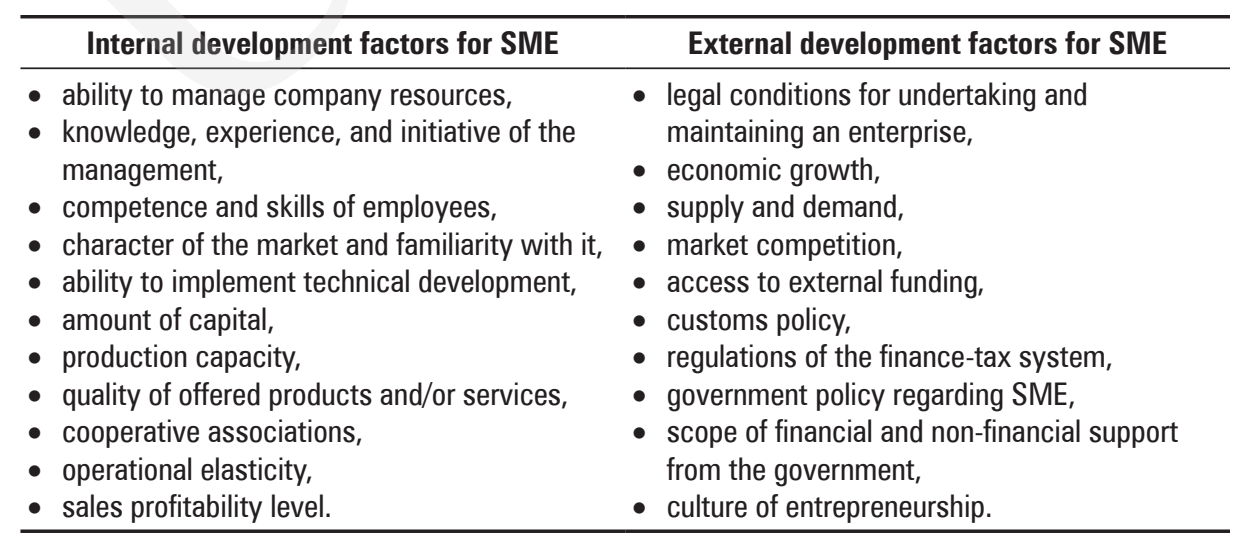

Source: Based on Matejun (2008).

\section{Key success factors}

Interest of market participants in key success factors is a consequence of the need to know the elements responsible for building competitive advantage, and achieving success in business. Due to the practical character of the issue, science constantly investigates it and, if possible, answers arising questions. According to the definition by Penc-Pietrzak 
(2010), key success factors dictate the growth, development, stagnancy, or collapse of an enterprise, determine in which sectors of the enterprise one should focus strategical decisions, in order to ensure its future success. These factors include, among others: current situation in the industry and in the sector, technological development, production capacity in relation to the needs of consumers, competitive position of the enterprise, possibilities of diversification of products and markets, technological advancement of production, level of innovation, cost levels, financial status, recognisability, image of the company on the market.

In terms of strategic management, subject literature indicates that key success factors relate to the issue of business survivability. One factor favourable to development, and thus survival of a micro or small business on the market, is effective application of knowledge possessed by the management, as well as utilising previous experiences in company management. Another factor is the use of strategic resources of the company, as well as permanent development of human capital (a learning enterprise). Yet another noteworthy element is the factor concerning innovation and competitiveness, as well as those pertaining to the issue of managing a company, including modern concepts of management matched to the type of enterprise. There also exists a classification concerning the psychological context, focused on the managers, that includes believing in one's own capabilities and decisions, as well as self-confidence.

The studies of the Lewiatan Confederation, composed of the largest employers in Poland, find the key success factors to be the ones responsible for creating competitiveness, such as: product and service quality level, their price, level of quality of customer service, product innovation, compatibility of the products and services with the needs of the client.

While discussing key success factors one should also note the issue of resources, which can be divided into: material, financial, organisational, informational, relational, human, and non-material. The main problems in the functioning of enterprises are limited resources, lack of systematised patterns of resource generation, and their future allocation. Lately, there is increased interest in non-material resources consisting of information capital, relational capital, as well as capital of knowledge. The essence of functioning of modern companies is their capability to produce knowledge, as well as transfering, gathering, and using its resources. An enterprise that purposefully manages its intellectual capital, will be able to identify and categorise non-material assets, and recognise the planes and areas of flow of information within the company. Therefore, the process of learning and accumulation of knowledge in the company will be accelerated, and the best practices and methods of presenting effective business examples of its use will be determined. The process of managing intellectual capital can cause an increase in the level of innovation and motivation of employees, as well as form action-oriented organizational culture. Discovering and skilful managing of the area of non-material assets enables an increase in the value of the company, and building a competitive advantage.

Relational resources allow the enterprise to develop relationships between the company and its environment, mainly clients and suppliers, therefore, creating optimised networks of connections.

Depending on the strength of the relationship, the company can acquire new outlets, and access to scarce resources, or base its operations on basic, easily-accessible resources.
Determinants of Business Survivability: Literature Review 
IJSR

6

Turbulent market conditions force companies to react and adapt quickly, which predestinates enterprises in which employees can instantly use knowledge resources, localise, acquire, and utilise these resources. Currently, an especially valuable resource is the information regarding the needs of clients, which, after proper processing and implementation can, in a longer period of time, lead to creating customer loyalty, therefore, influencing survivability of the company. Properly formed resources become key success factors. According to Skawińska and Zalewski (2016) types of capital include:

- intellectual capital (human, social, structural, relational capital),

- technological capital,

- financial capital.

Positive correlations between the types of capital form key success factors that include: behavioral, institutional, and structural factors. Regarding the issue of nonmaterial capital, which includes human capital, one should focus attention on elements related directly to employees - such as: skills, experience, knowledge, talent, perseverance, inventiveness. These elements provide foundations for building proper human behaviours in the functioning of business enterprises.

\section{Studies of survivability}

In the subject literature, one can find Polish and foreign studies regarding multidimensional empirical research. Due to their complex form, they should be categorised as studies of macro and microeconomic determinants. The first category encompasses factors relating to the market investigated by Agarwal and Audretsch (2001), in relations to sector dynamics, who found that life cycle of a sector significantly correlates with the level of survivability. In the initial phase, a high number of entries into and exits from a sector were observed. Subsequently, the numer of entries and exits is stabilised, companies establish their position, chances for innovation decrease, and the level of competition rises. The highest probability of leaving the market was determined for later stages of the life cycle of the sector. According to Gawel (2011), high technology sectors have a higher risk of collapse than enterprises comparable in size in other sectors of the economy. Certain differences in study results arise in the context of geographical location of companies. Strotmann (2007) states that companies in rural areas show higher chances of survival than those established in metropolitan areas. This was not confirmed by independent studies by Fotopoulos and Louri (2000), which noted that enterprises from larger cities show a higher level of survivability. In Polish studies by Gawel (2011), companies from the Łódzkie Voivodeship confirmed higher survivability in urban, more densely populated regions. It was justified by a higher absorption capacity of the market, and higher demand. Another factor is the business cycle. Mahmood (2000) presents a high correlation between market situation and the number of entries and exits, which seems reasonable. It was confirmed by Ptak-Chmielewska (2012) in Polish studies describing the level of enterprise population dynamics. It confirms the - quite visible on the market - phenomenon of economic boom, most often seen in certain periods for individual branches of the economy or sectors with a similar profile of activity. While discussing macroeconomic factors of business survivability, one should note the 
aspect of sector attractivenes, which highly influences the number of market entries of new companies, as evidenced by Audretsch et al. (2000) in the study of companies established in the Netherlands. It was justified by a higher level of motivation due to relatively higher profits from the planned enterprise.

Literature pertaining to the research of microeconomic determinants shows numerous studies that confirm the influence of investing in research and development on business survivability. This is confirmed by studies carried out in the USA, Japan, the Netherlands, and Spain. They show that companies investing in R\&D department increase the probability of staying on the market. Kimura and Fujii (2003) present research carried out in Japanese companies that have shown a positive influence of investing in advertising on business survivability and its success on the market. These results were also confirmed by Esteve-Pérez and Mañez-Castillejo (2008) who found a relationship between survival and activity in the area of promotion, as well as research and development. Ortega-Argilés and Moreno (2007) noted that, while in big companies investments in process innovation decrease failure probability, they do not influence the survivability of micro and small enterprises. Taking into consideration the age of the company from the moment of its establishment, one should analyse the research into Polish companies, carried out by Gaweł (2010), who shows that the first two years of existence are the most difficult for the company. During that time, the business familiarises itself with its market environment, verifies strategy efficiency, acquires new business contacts, and builds its market image. This was also confirmed by Agarwal and Gort (1996), who found a strong correlation between the age of an enterprise and its survivability. According to Gawel (2010), there is a visible difference in survivability of new companies in EU countries, and those established in Poland. In the EU, survivability within two years from entering the market is $73 \%$, while in Poland it is approximately $50 \%$. However, no direct causes for such differences were determined. Using a survey and data obtained from Portuguese Ministry of Labour, Geroski et al. (2007) observed that large companies stay on the market significantly longer than micro and small ones, which confirms that the size of an enterprise influences its survivability. Similar conclusions were reached by Audretsch (1991), while analysing the market of American companies, using data from U.S. Small Business Data Base for 4-year and 10-year periods, without distinguishing individual fields of operation. An interesting survivability determinant, often investigated both in Poland and abroad, is the age of the entrepreneur. A hypothesis was formed, that the older the businessman, the higher the survivability of their business. However, study results have shown contradictory information and it is impossible to unequivocally state that more advanced age of the entrepreneur positively influences business success. Nonetheless, while studying the factor of previous experience in managing enterprises, Agarwal and Gort (1996) found it to be favourable for the future of the company. The aforementioned factor is discussed in greater detail by Geroski (2007), using the terms "tacit knowledge" and "explicit knowledge", where the level of flow of tacit knowledge between employees influences the success of the enterprise. The last of the survivability factors related to the person of the entrepreneur is their gender. Independent studies provide contradictory conclusions, and it is not possible to view gender as a factor determining business survivability.
Determinants of Business Survivability: Literature Review 


\section{IJSR}

6

\section{Conclusions}

The main goal of this study was to identify determinants of survivability and factors responsible for success of companies. The study resulted in defining the main concepts, as well as compiling factors into two categories: micro and macroeconomic. It was observed that if the listed symptoms occurr, the enterprise might be prone to collapse and termination of activity. Unfortunately, only financial symptoms are clear, and do not pose problems in finding them. Systematic and thorough observation of a company can immediately warn the stakeholders about alarming symptoms. Conclusions reached as a result of the analysis of key success factors may provide guidance for newly-established enterprises or people planning to start a company in the future. Key success factors pinpoint the areas in the functioning of the company, that may become indispensible in building competitive position and remaining on a highly concentrated market. While providing particular resources (material, financial, organisational, informational, relational, human, non-material), the company should pay additional attention to the issues regarding the flow of knowledge, including the experience of employees, as well as ensure innovativeness, since, as was observed in previous studies, both elements have a significant influence on business survivability, regardless of its origin, be it Polish or foreign. According to the Lewiatan Confederation, key success factors should also include such basic elements as ensuring a positive relations between the price and quality of products and services, client satisfaction leading to brand loyalty, as well as maintaining a high level of customer services. It can be stated with all certainty that, even with favourable economic conditions, without fulfilling the aforementioned conditions, an enterprise will have difficulties in adapting to new conditions, and, in consequence, in remaining on the market.

The compiled empirical research - carried out in various time periods, and different countries - presents common conclusions as, for instance, a strong correlation between the phase of the life cycle of the sector and survivability, or between general economic situation and survivability. Both comparisons relate to macroenvironment, while internal determinants include investing in research, development, and advertising as favourable to remaining on the market. Studies unequivocally confirmed that companies investing in these areas can survive longer. Authors of these studies also analysed the size of companies, and it can be concluded that large companies are better at surviving on the market. The relationship between age or gender of the entrepreneur and business survivability was not confirmed. The compilation presented by Gawel shows a significant difference in collapses of newly-established companies in Poland and those in other countries of the EU, where survivability index equalled $50 \%$ and $73 \%$, respectively. Presented data provides basis for future research, the goal of which would be to determine the causes for existence of such visible differences. 


\section{References}

Agarwal, R., Audretsch, D.B. (2001). Does Entry Size Matter? The Impact of the Life Cycle and Technology on Firm Survival. The Journal of Industrial Economics, vol. 49, no. 1, pp. 21-43.

Agarwal, R., Gort, M. (1996). The Evolution of Markets and Entry, Exit and Survival of Firms. The Review of Economics and Statistics, vol. 78, no. 3, pp. 489-498.

Audretsch, D.B. (1991). New Firm Survival and the Technological Regime. The Review of Economics and Statistics, vol. 73, no. 3, pp. 441-450.

Audretsch, D.B., Houweling, P., Thurik, A. (2000). Firm Survival in the Netherlands. Review of Industrial Organization, vol. 16, no. 1, pp. 1-11.

Esteve-Pérez, S., Mañez-Castillejo, J.A. (2008). The Resource-Based Theory of the Firm and Firm Survival. Small Business Economics, vol. 30, no. 3, pp. 231-249.

Fotopoulos, G., Louri, H. (2000). Location and Survival of New Entry. Small Business Economics, vol. 14 , no. 4, pp. 311-321.

Gaweł, A. (2010). Czynniki wpływające na przetrwanie lub upadek przedsiębiorstwa. Ekonomika i Organizacja Przedsiębiorstwa, $\mathrm{nr} 9$.

Gaweł, A. (2011). Struktura sektora przedsiębiorstw w województwach jako czynnik wpływający na tworzenie i upadek firm. Studia Regionalne i Lokalne / Europejski Instytut Rozwoju Regionalnego i Lokalnego UW, Sekcja Polska Regional Studies Association, nr 1.

Geroski, P.A., Mata, J., Portugal, P. (2007). Founding Conditions and the Survival of New Firms, DRUID Working Papers, no. 11.

Grunert, K.G., Ellegaard, C. (1992). The Concept of Key Success Factors: Theory and Method, MAPP.

Kimura, F., Fujii, T. (2003). Globalizing Activities and the Rate of Survival: Panel Data Analysis on Japanese Firms. Journal of the Japanese and International Economics, no. 17.

Mahmood, T. (2000). Survival of Newly Founded Business: A Log-Logistic Model Approach, Small Business Economics, vol. 14.

Mączyńska-Ziemacka, E. (2009). Upadłości przedsiębiorstw - dysfunkcje, ich przyczyny. Zeszyty naukowe Małopolskiej Wyższej Szkoły Ekonomicznej w Tarnowie, no. 2(13).

Matejun, M. (2008). Czynniki rozwoju matych i średnich przedsiębiorstw na podstawie badań w mikroregionie łódzkim. Teoria i praktyka zarządzania rozwojem organizacji, Wydawnictwo Politechniki Łódzkiej, Łódź.

Ortega-Argilés, R., Moreno, R. (2007). Firm Competitive Strategies and the Likelihood of Survival. The Spanish Case. Papers on Entrepreneurship, Growth and Public Policy, no. 5.

Penc-Pietrzak, I. (2010). Planowanie strategiczne w nowoczesnej firmie, Warszawa.

Ptak-Chmielewska, A. (2012). Likwidacja a upadłość przedsiębiorstw w Polsce. In: S. Morawska (ed.), Ekonomia $i$ prawo upadłości przedsiębiorstw. Zarządzanie przedsiębiorstwem w kryzysie, Oficyna Wydawnicza SGH, Warszawa.

Skawińska, E., Zalewski, R.I. (2016). Konkurencyjność - kluczowe czynniki sukcesu przedsiębiorstw XXI wieku. Przegląd Organizacji, nr 3, Towarzystwo Naukowe Organizacji i Kierownictwa, Warszawa.

Strotmann, H. (2007). Entrepreneurial Survival. Small Business Economic, vol. 28, no. 1, pp. 87-104. 
